\title{
A Survey Based on Analysis of Physiological Change of Menstrual Cycle among Female of Reproductive Age Group
}

\author{
S. Shreya ${ }^{1}$, Dr. M. P. Brundha ${ }^{2}$ \\ ${ }^{1}$ BDS II, Saveetha Dental College \\ ${ }^{2}$ Department of Pathology, Saveetha Dental College
}

\begin{abstract}
Aim: To analyze the physiological change of menstrual cycle among females of reproductive age group by means of a questionnaire based survey. Objective: The major physiological changes and their intensity of symptoms is determined by the age group of the female, volume of blood flow, successive interval between each menstrual cycle and the various other changes that occurs after the birth of first child and consecutive pregnancies and child birth. Background: The menstrual cycle is the regular natural change that occurs in the uterus and ovaries that make pregnancy possible. The cycle is required for the production of ovocytes, and for the preparation of the uterus for pregnancy. Studies suggest that up to $80 \%$ of women report having some symptoms during the one to two weeks prior to menstruation. Analysis may differ according to age group. Reason: The various changes in the menstrual cycle among teen aged girls and those women prior to menopause remains a significant factor of study in order to know the physiological change of reproductive cycle among females.
\end{abstract}

Keywords: Menstrual periods, regularity, Blood flow, Physiological changes, Dysmenorrhea, Pregnancy

\section{Introduction}

The menstrual cycle is the monthly series of changes a woman's body goes through in preparation for the possibility of pregnancy. Each month, one of the ovaries releases an egg by a process called ovulation. At the same time, hormonal changes prepare the uterus for pregnancy. If ovulation takes place and the egg isn't fertilized, the lining of the uterus sheds through the vagina. This is a menstrual period. The menstrual cycle, which is counted from the first day of one period to the first day of the next, isn't the same for every woman. Menstrual flow might occur every 21 to 35 days and last two to seven days ${ }^{(1,2)}$. For the first few years after menstruation begins, long cycles are common. However, menstrual cycles tend to shorten and become more regular as you age.

Menstrual irregularities can be caused by a variety of conditions, including pregnancy, hormonal imbalances, infections, malignancies, diseases, trauma, and certain medications. Tracking your menstrual cycles can help you understand what's normal for you, time ovulation and identify important changes such as a missed period or unpredictable menstrual bleeding ${ }^{(3)}$. While menstrual cycle irregularities usually aren't serious, sometimes they can signal health problems. Irregular cycles or irregular periods are an abnormal variation in length of menstrual cycles in a female. A female usually experiences cycle length variations of up to eight days between the shortest and longest cycle lengths. Lengths ranging between eight and 20 days are considered moderately irregular ${ }^{(4,5)}$. The study is done to analyze the changes that occur in a female belonging to reproductive age group and the significant reasons that contribute for the changes.

\section{Materials and Method}

- Research Design: Descriptive in nature

- Sampling technique: Stratified Random Sampling

- Data collective instrument: Questionnaire

- Sample Size: 50 Respondents (25 for each age group)

- Method: Based on the age group, two different questionnaires are prepared and given to 50 women belonging to age group 14-23 and 24-50, that is 25 women of each Category respectively in a random population and the survey is done.

- Data analysis and conclusion: To synchronize the data received through questionnaire and thereby analyze the physiological changes of menstrual cycle.

\section{Data Analysis and Interpretation}

3.1 Women of age group 14-23 
International Journal of Science and Research (IJSR)

ISSN (Online): 2319-7064

Index Copernicus Value (2013): 6.14 | Impact Factor (2015): 6.391

AGE OF ATTAINING PUBERTY

\begin{tabular}{|c|c|c|}
\hline Option & Range & $\begin{array}{c}\text { No of } \\
\text { Respondents }\end{array}$ \\
\hline A & Between 10- 14 Yrs & 12 \\
\hline B & Between 14- 18 Yrs & 13 \\
\hline
\end{tabular}

INTERVALS OF MENSTRUATION

\begin{tabular}{|c|l|c|}
\hline Option & \multicolumn{1}{|c|}{ Range } & $\begin{array}{c}\text { No of } \\
\text { Respondents }\end{array}$ \\
\hline A & Before 28 Days & 4 \\
\hline B & Exactly on 28th Day & 12 \\
\hline C & After 28 Days & 9 \\
\hline
\end{tabular}

REGULARITY OF MENSTRUATION

\begin{tabular}{|c|l|c|}
\hline Option & \multicolumn{1}{|c|}{ Response } & $\begin{array}{c}\text { No of } \\
\text { Respondents }\end{array}$ \\
\hline A & Yes & 13 \\
\hline B & No & 12 \\
\hline
\end{tabular}

\section{Age of Attaining Puberty}

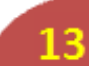

A Between 10-14 Yrs

B Between 14-18 Yrs
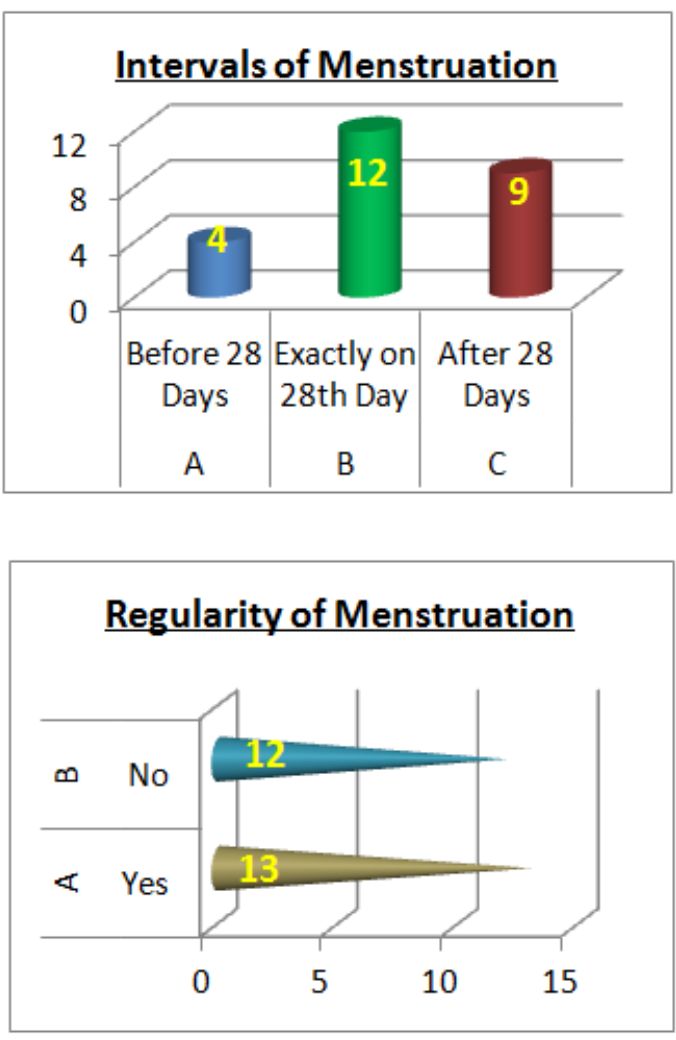

IF YES - REASONS CONTRIBUTING TO REGULAR MENSTUATION

\begin{tabular}{|c|l|c|}
\hline Option & \multicolumn{1}{|c|}{ Reason } & $\begin{array}{c}\text { No of } \\
\text { Respondents }\end{array}$ \\
\hline A & Proper Diet & 8 \\
\hline B & Physical Fitness & 2 \\
\hline C & Genetic Factors & 3 \\
\hline
\end{tabular}

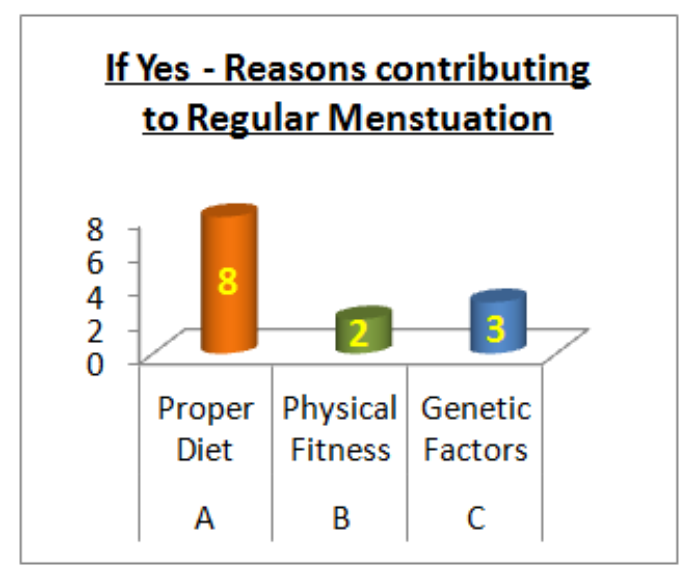

Volume 5 Issue 6, June 2016 www.ijsr.net

Licensed Under Creative Commons Attribution CC BY 
International Journal of Science and Research (IJSR)

ISSN (Online): 2319-7064

Index Copernicus Value (2013): 6.14 | Impact Factor (2015): 6.391

IF NO - REASON FOR IRREGULAR MENSTRUATION

\begin{tabular}{|c|l|c|}
\hline Option & \multicolumn{1}{|c|}{ Reason } & $\begin{array}{c}\text { No of } \\
\text { Respondents }\end{array}$ \\
\hline A & Improper Diet & 3 \\
\hline B & Emotional Imbalance & 6 \\
\hline C & Genetic Factors & 3 \\
\hline
\end{tabular}

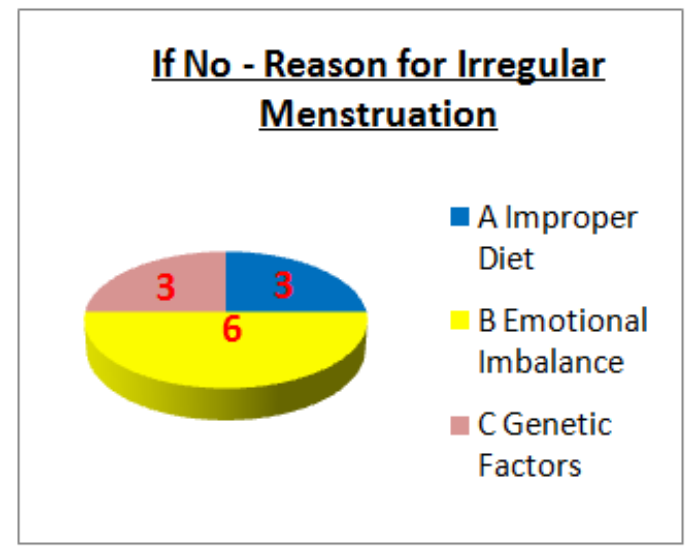

VOLUME OF BLOOD FLOW

\begin{tabular}{|c|l|c|}
\hline Option & \multicolumn{1}{|c|}{ Range } & $\begin{array}{c}\text { No of } \\
\text { Respondents }\end{array}$ \\
\hline A & Normal (1 - 3 pads a day $)$ & 15 \\
\hline B & Moderate (4 - 6 pads a day) & 10 \\
\hline C & Heavy (7 - 8 pads a day) & 0 \\
\hline
\end{tabular}

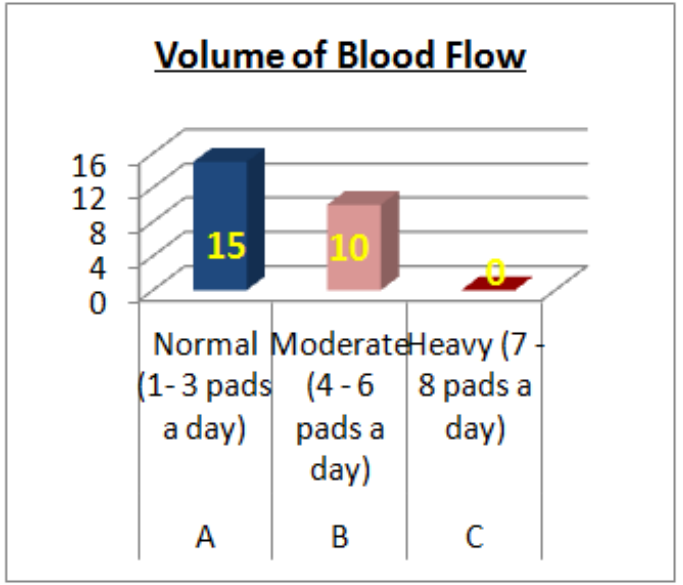

NO OF DAYS OF BLEEDING DURING EACH PERIODS

\begin{tabular}{|c|l|c|}
\hline Option & \multicolumn{1}{|c|}{ Range } & $\begin{array}{c}\text { No of } \\
\text { Respondents }\end{array}$ \\
\hline A & 3 Days & 12 \\
\hline B & 5 Days & 13 \\
\hline C & 7 Days and more & 0 \\
\hline
\end{tabular}

\section{No of Days of bleeding during each periods}

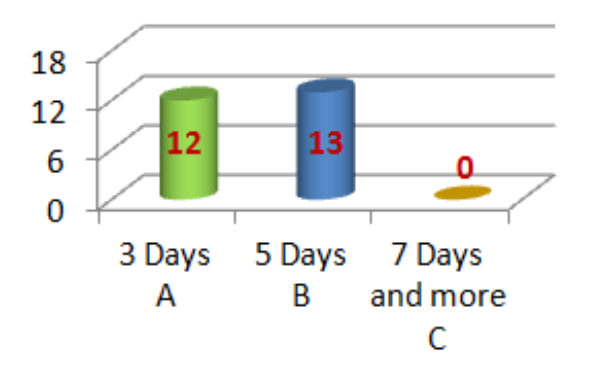

CHANGE IN VOLUME OF BLOOD FLOW

\begin{tabular}{|c|l|c|}
\hline Option & \multicolumn{1}{|c|}{ Range } & $\begin{array}{c}\text { No of } \\
\text { Respondents }\end{array}$ \\
\hline A & Increased & 6 \\
\hline B & Decreased & 3 \\
\hline C & Remains the same & 16 \\
\hline
\end{tabular}

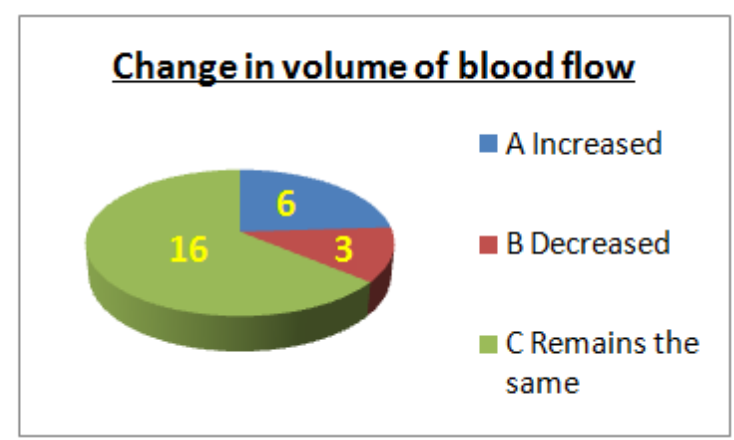

Volume 5 Issue 6, June 2016 www.ijsr.net

Licensed Under Creative Commons Attribution CC BY 
International Journal of Science and Research (IJSR)

ISSN (Online): 2319-7064

Index Copernicus Value (2013): 6.14 | Impact Factor (2015): 6.391

PRE MENSTRUAL SYMPTOMS

\begin{tabular}{|c|l|c|}
\hline Option & \multicolumn{1}{|c|}{ Symptoms } & $\begin{array}{c}\text { No of } \\
\text { Respondents }\end{array}$ \\
\hline A & Giddiness & 8 \\
\hline B & Stomach pain & 9 \\
\hline C & Severe Head ache & 1 \\
\hline D & None of the above & 7 \\
\hline
\end{tabular}

CONSUMPTION OF PILLS TO REGULATE PERIODS

\begin{tabular}{|c|l|c|}
\hline Option & Response & $\begin{array}{c}\text { No of } \\
\text { Respondents }\end{array}$ \\
\hline A & Yes & 16 \\
\hline B & No & 9 \\
\hline
\end{tabular}

\section{Women of age group 24-50}

AGE OF ATTAINING PUBERTY

\begin{tabular}{|c|l|c|}
\hline Option & \multicolumn{1}{|c|}{ Range } & $\begin{array}{c}\text { No of } \\
\text { Respondents }\end{array}$ \\
\hline A & Between 10- 14 Yrs & 14 \\
\hline B & Between 14- 18 Yrs & 11 \\
\hline
\end{tabular}

REGULARITY OF PERIODS BEFORE CHILD BIRTH

\begin{tabular}{|c|l|c|}
\hline Option & \multicolumn{1}{|c|}{ Response } & $\begin{array}{c}\text { No of } \\
\text { Respondents }\end{array}$ \\
\hline A & Yes & 13 \\
\hline B & No & 12 \\
\hline
\end{tabular}

REGULARITY OF PERIODS AFTER CHILD BIRTH

\begin{tabular}{|c|l|c|}
\hline Option & \multicolumn{1}{|c|}{ Response } & $\begin{array}{c}\text { No of } \\
\text { Respondents }\end{array}$ \\
\hline A & Yes & 12 \\
\hline B & No & 13 \\
\hline
\end{tabular}
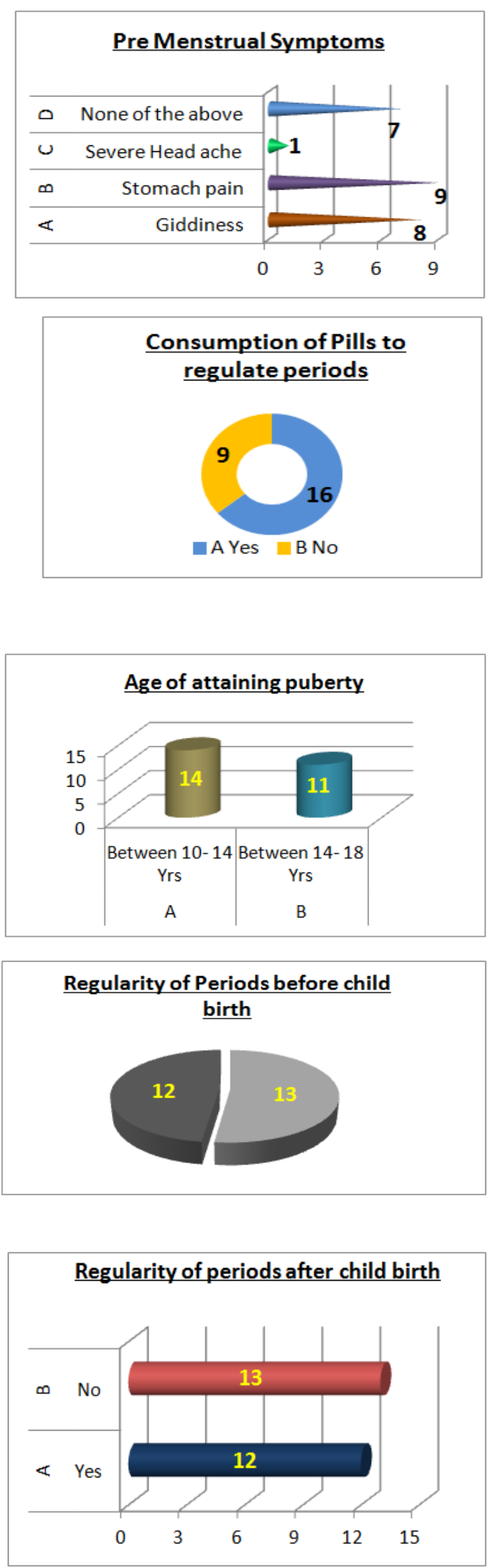

Volume 5 Issue 6, June 2016 www.ijsr.net

Licensed Under Creative Commons Attribution CC BY 
CHANGES IN PERIODS AFTER CHILD BIRTH

\begin{tabular}{|c|l|c|}
\hline Options & \multicolumn{1}{|c|}{ Changes } & $\begin{array}{c}\text { No of } \\
\text { Respondents }\end{array}$ \\
\hline A & Colour of Blood & 14 \\
\hline B & Volume of flow & 6 \\
\hline C & Viscosity of the blood & 5 \\
\hline
\end{tabular}

PROLONGING CHAGES AFTER 2ND CHILD BIRTH

\begin{tabular}{|c|l|c|}
\hline Option & \multicolumn{1}{|c|}{ Response } & $\begin{array}{c}\text { No of } \\
\text { Respondents }\end{array}$ \\
\hline A & Yes & 14 \\
\hline B & No & 2 \\
\hline C & $\begin{array}{l}\text { Not applicable, One Child } \\
\text { only }\end{array}$ & 9 \\
\hline
\end{tabular}

\section{Changes in periods after child birth}

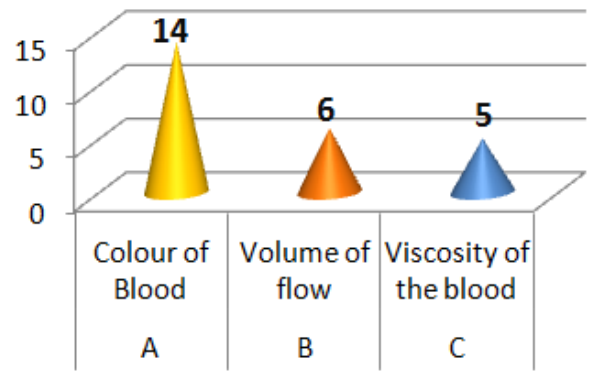

\section{Prolonging changes after 2 nd child birth}

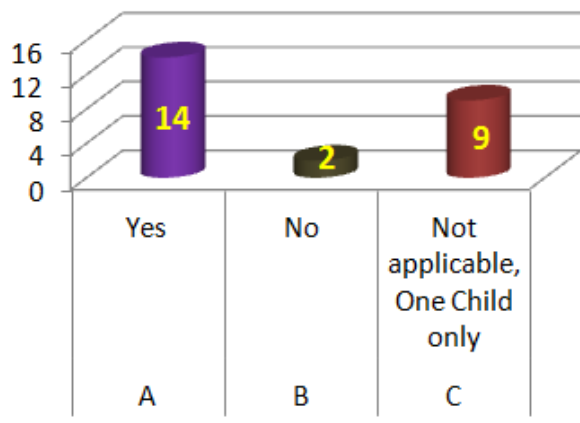

AWARENESS OF THE INFLUENCE OF THYROID ON HORMONAL BALANCING EFFECT ON MENSTRUATION

\begin{tabular}{|c|l|c|}
\hline Option & \multicolumn{1}{|c|}{ Response } & $\begin{array}{c}\text { No of } \\
\text { Respondents }\end{array}$ \\
\hline A & Yes & 13 \\
\hline B & No & 12 \\
\hline
\end{tabular}

\section{Awareness of the influence of Thyriod} on hormonal balancing effect on menstruation

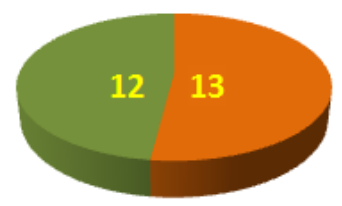

\section{Discomforts Experienced}

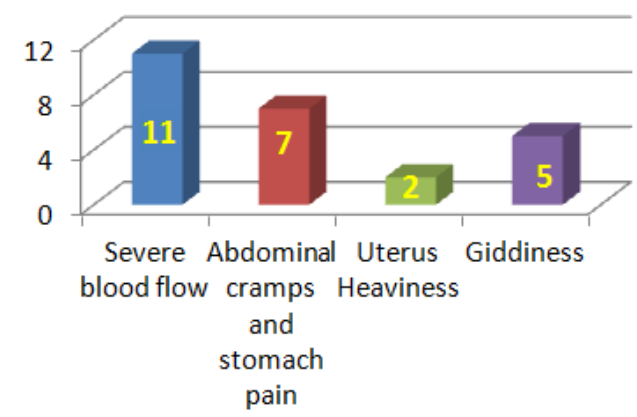

Volume 5 Issue 6, June 2016 www.ijsr.net 


\section{International Journal of Science and Research (IJSR) \\ ISSN (Online): 2319-7064}

Index Copernicus Value (2013): 6.14 | Impact Factor (2015): 6.391

MAXIMUM INTENSITY FELT

\begin{tabular}{|c|l|c|}
\hline Option & \multicolumn{1}{|c|}{ Complications } & $\begin{array}{c}\text { No of } \\
\text { Respondents }\end{array}$ \\
\hline A & During Adolescent & 11 \\
\hline B & Before Pregnancy & 9 \\
\hline C & After 1st Child birth & 5 \\
\hline D & After 2nd Child birth & 0 \\
\hline
\end{tabular}

MEASURES TAKEN TO OVERCOME THE DIFFICULTY

\begin{tabular}{|c|l|c|}
\hline Option & \multicolumn{1}{|c|}{ Complications } & $\begin{array}{c}\text { No of } \\
\text { Respondents }\end{array}$ \\
\hline A & By taking pain killers & 16 \\
\hline B & By natural home remedies & 5 \\
\hline C & Both & 4 \\
\hline
\end{tabular}

\section{Response for maximum intensity felt}

0

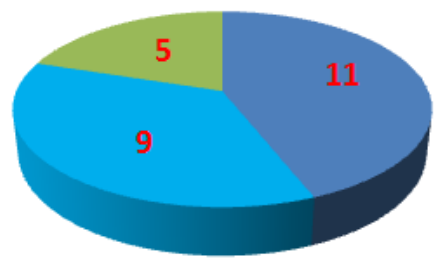

- During Adolescent Before Pregnancy

After 1st Child birth After 2nd Child birth

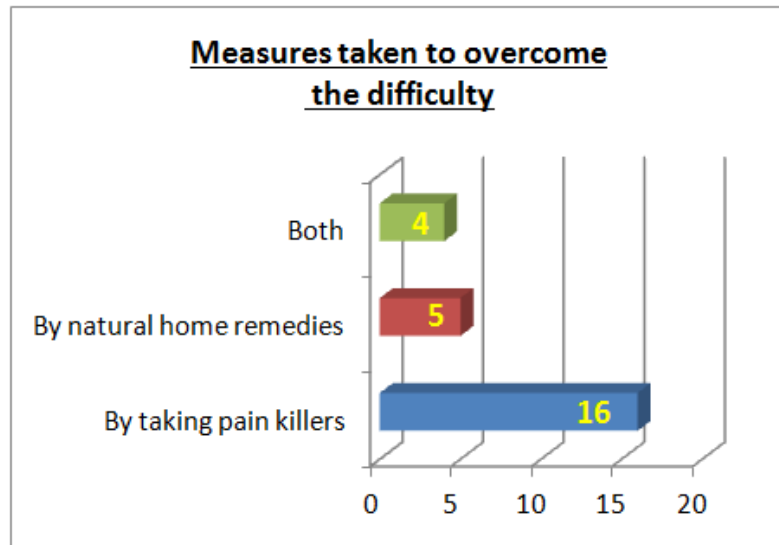

CONTRACEPTIVE TREATMENT -IF UNDERGONE AFTER 1ST PREGNANCY

\begin{tabular}{|c|l|c|}
\hline Option & \multicolumn{1}{|c|}{ Response } & $\begin{array}{c}\text { No of } \\
\text { Respondents }\end{array}$ \\
\hline A & Yes & 9 \\
\hline B & No & 16 \\
\hline
\end{tabular}

Contraceptive treatment - If undergone after 1st pregnancy

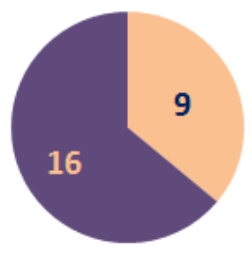

INCREASE IN THE BLOOD FLOW CORRESPONDING TO CONTRACEPTIVE TREATMENT

\begin{tabular}{|c|l|c|}
\hline Option & \multicolumn{1}{|c|}{ Response } & $\begin{array}{c}\text { No of } \\
\text { Respondents }\end{array}$ \\
\hline A & Yes & 3 \\
\hline B & No & 6 \\
\hline
\end{tabular}

\section{INCREASE IN THE BLOOD FLOW \\ CORRESPONDING TO CONTRACEPTIVE TREATMENT}

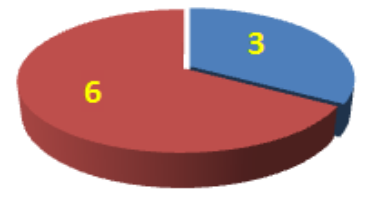

\begin{tabular}{|c|c|c|c|}
\hline Physiological changes in \\
menstrual cycle & $\begin{array}{c}\mathbf{1 4 - 2 3} \\
\text { years of } \\
\text { age }\end{array}$ & $\begin{array}{c}\mathbf{2 4 - 5 0} \\
\text { year of } \\
\text { age }\end{array}$ & Total \\
\hline With regular periods & 13 & 12 & 25 \\
\hline Without regular periods & 12 & 13 & 25 \\
\hline Total & 25 & 25 & 50 \\
\hline
\end{tabular}

$$
\text { Total }
$$

\section{Statistical Analysis - Chi-Square Test}

To check whether there is any significant relation between the age group of the people and the physiological changes of menstrual cycle among various age groups at the reproductive stage

\section{Volume 5 Issue 6, June 2016} www.ijsr.net

Licensed Under Creative Commons Attribution CC BY 


\section{International Journal of Science and Research (IJSR) \\ ISSN (Online): 2319-7064}

Index Copernicus Value (2013): 6.14 | Impact Factor (2015): 6.391

Null Hypothesis $\mathrm{H}_{0}=$ There is no significant relation between the age group of people and the physiological changes of menstrual cycle

Alternate Hypothesis $\mathrm{H}_{1}=$ There is significant relation between the age group of people and the physiological changes of menstrual cycle

\section{$\mathrm{N}=100$}

$\left(\mathbf{A}_{\mathbf{i}} \mathbf{B}_{\mathbf{j}}\right)_{\mathrm{e}}=\left(\mathbf{A}_{\mathbf{i}} * \mathbf{B}_{\mathbf{j}}\right) / \mathbf{N}$

$(13) \mathrm{e}=(25 * 25) / 50=12.5$

(12) $\mathrm{e}=(25 * 25) / 50=12.5$

(12) $\mathrm{e}=(25 * 25) / 50=12.5$

$(13) \mathrm{e}=(25 * 25) / 50=12.5$

\begin{tabular}{|c|c|c|c|}
\hline Observed (O) & Expected (E) & $(\mathbf{O}-\mathbf{E})^{\mathbf{2}}$ & $(\mathbf{O - E})^{2} / \mathbf{E}$ \\
\hline 13 & 12.5 & 0.25 & 0.02 \\
\hline 12 & 12.5 & 0.25 & 0.02 \\
\hline 12 & 12.5 & 0.25 & 0.02 \\
\hline 13 & 12.5 & 0.25 & 0.02 \\
\hline & & Total & 0.08 \\
\hline
\end{tabular}

From Tables for (r-1) and (c-1) degrees of freedom,

Where, $r=$ No. of Rows,

$\mathrm{c}=$ No. of columns

$(2-1)(2-1)=1$ d.f.

$\chi_{\mathrm{tab}}^{2}=3.84$ (At 0.05 )

since,

$\chi_{\text {cal }}^{2} \chi_{\text {tab }}^{2}$

$\mathrm{H}_{0}$ is accepted

\section{Inference}

There is no significant relation between the age group of people and the physiological changes of menstrual cycle among various age groups at the reproductive stage.

\section{Discussion}

The physiological change of menstrual cycle among females of reproductive age group was taken as study and it was found that up to $80 \%$ of women report having some symptoms during one or two weeks prior to menstruation. These symptoms interfere with normal life and therefore qualify as premenstrual symptom which was common in 60$80 \%$ of women and in $3-8 \%$ of them, the symptoms were severe.

The study aimed at analyzing the physiological changes among females categorized based on age group in order to differentiate the changes that occurs, and thereby synchronize the study to get a significant knowledge on the various changes such as dysmenorrhea, uterus heaviness, abdominal cramps, severe stomach and head pain and associated disorders that prevailed among them. Through the study it was revealed that most of the,

Adolescent teen aged girls and women of adult age,

- Have attained their puberty in a normal age between 1418 years

- They get their periods every month on 28 day cycle which lasts for about 3-5 days
- The volume of blood flow is normal, they use 1-3 pads a day and the flow of blood remains almost the same between successive periods

The survey shows that the responders (particularly the adolescent girls) believed that proper diet contributed to their regular menstrual cycle followed by genetic factors and physical fitness. Many have responded that emotional imbalance was the key reason for irregular menstrual cycle. The prime premenstrual symptom noticed by them was abdominal cramps and stomach pain while a few also had experienced head ache and fatigue and it was also understood that the responders showed no interest in consuming pills to regulate periods.

On the other hand, most of the adult women who have undergone pregnancy and child birth have responded that there was no significant change in the blood flow between successive pregnancies. Even here, factors such as abdominal cramps seemed to be the key premenstrual symptoms even though they were felt with their maximum intensity during the adolescent age group. Study also revealed that there is no relation between change in the volume of blood flow and the contraceptive treatment, if undergone.

\section{Conclusion}

Through all these obtained results it is understood that the physiological changes such as dysmenorrhea, uterus heaviness, abdominal cramps, severe stomach and head pain and associated disorders are common among females of all age group irrespective of their age and stage. The woman given birth to first child, second child has not impacted the menstrual cycle and the study reveals that the premenstrual syndrome, amount of blood flow and the number of days are common among the adolescent age group and the reproductive stages of a female.

\section{References}

[1] Biggs, WS; Demuth, RH (15 October 2011). "Premenstrual syndrome and premenstrual dysphoric disorder.". American family physician 84 (8): 918-24.

[2] American Academy of Pediatrics Committee on, Adolescence; American College of Obstetricians and Gynecologists Committee on Adolescent Health, Care; Diaz, A; Laufer, MR; Breech, LL (November 2006). "Menstruation in girls and adolescents: using the menstrual cycle as a vital sign."

[3] Martin RD (2007). "The evolution of human reproduction: a primatological perspective". Am. J. Phys. Anthropol. Suppl 45: 59-84.

[4] Sharma P, Malhotra C, Taneja DK, Saha R (2008). "Problems related to menstruation amongst adolescent girls". Indian J Pediatr 75 (2): 125-9.

[5] https://en.wikipedia.org > wiki > Physiological changes of menstrual cycle among females. 


\section{International Journal of Science and Research (IJSR) \\ ISSN (Online): 2319-7064}

Index Copernicus Value (2013): 6.14 | Impact Factor (2015): 6.391

\section{Appendix}

Analysis of physiological change of menstrual cycle among females of reproductive age group

(A QUESTIONNAIRE BASED STUDY-Age group 14-23) NAME: AGE:

1. At what age did you attain puberty?

a) Between 10-14 Years

b) Between 14-18 Years

2. At what intervals do you get your periods?

a) Before 28 days

b) Exactly on $28^{\text {th }}$ day

c) After 28 days

3. Is your period regular?

a) Yes b) No

4. If yes, what of the below reasons contribute to your regular menstrual cycle?

a) Proper diet

b) Physical fitness

c) Genetic factors

5. If No, what do you think as the reason that contributes to irregular menstrual cycle?
a) Improper diet
b) Emotional imbalance
c) Genetic factors

6. What is the approximate volume of blood flow during each menstrual cycle?

a) Normal (1-3 pads a day)

b) Moderate (1-6 pads a day)

c) Abnormal (1-8 pads a day)

7. For how many days does the bleeding last during each periods?

a) 3 days, b) 5 days c) 1 week and more

8. How is the change in volume of blood flow between successive periods/

a) Increased

b) Decreased

c) Remains the same

9. Do you suffer dysmenorrhea or any of the following premenstrual symptoms?

a) Giddiness

b) Abdominal cramps and stomach pain

c) Severe headaches and other complications

d) None of the above
10. Do you believe that consuming pills would be a good option to regulate the periods?

a) Yes b) No

Analysis of physiological change of menstrual cycle among females of reproductive age group

(A QUESTIONNAIRE BASED STUDY-Age group 24-50)

NAME: AGE:

1. At what age did you attain puberty?

a) Between 10-14 Years

b) Between 14-18 Years

2. Was the period regular before child birth?
a) Yes b) No

3. Is your period regular even after child birth? a) Yes b) No

4. Did you notice any of the following changes in your periods after child birth?
a) Colour of the blood
b) Volume of flow
c) Viscosity of the blood

5. Did they prolong even after $2^{\text {nd }}$ child birth?
a) Yes
b) No
c) Not applicable, one child only

6. Are you aware of the influence of thyroid on the hormonal balancing effect on mensuration?

a) Yes b) No

7. Have you ever experienced the below discomforts?
a) Severe blood flow
b) Abdominal cramps and stomach pain
c) Uterus heaviness
d) Giddiness

8. When did you feel the maximum intensity of the above complications?
a) During Adolescent
b) Before Pregnancy
c) After $1^{\text {st }}$ child birth
d) After $2^{\text {nd }}$ child birth

9. What measures do you take in order to overcome the above difficulties?
a) By taking pain killers
b) By natural homemade remedies
c) Both

10. Did you undergo any contraceptive treatment procedures after $1^{\text {st }}$ pregnancy?
a) Yes
b) No
a) Yes
b) No

If yes, was there any increase in the blood flow after the treatment? 